\title{
Robotic Assisted Resection of Benign Multicystic Mesothelioma: Case Report
}

\author{
Robotik Yardimlı \\ Benign Multikistik Mezotelyoma Rezeksiyonu
}

Fatih SANLIKAN, Ahmet GÖÇMEN ${ }^{\mathrm{a}}$

${ }^{a}$ Clinic of Gynecology and Obstetrics, Ümraniye Training and

Research Hospital, İstanbul

Geliş Tarihi/Received: 01.06 .2015

Kabul Tarihi/Accepted: 24.09.2015

Yazıșma Adresi/Correspondence:

Fatih ŞANLIKAN

Ümraniye Training and

Research Hospital,

Clinic of Gynecology and Obstetrics,

İstanbul,

TÜRKIYE/TURKEY

fatihroland@ hotmail.com
Copyright ( $) 2017$ by Türkiye Klinikleri
ABSTRACT Benign multicystic mesothelioma is an uncommon tumor of the peritoneum which is derived from mesenchymal cells histologically. Nonspecific symptoms of the disease causes difficulties in pre-operative diagnosis. We here reported a case of benign cystic mesothelioma which was found incidentally during the robotic assisted tubal surgery. A 34-year-old female was admitted to the clinic with the request of tubal reversal for return of fertility. Intra operative exploration of the abdomen showed that the obliteration of the cul-de-sac with multiloculated, thin-walled and translucent cysts filled with clear fluids. The frozen section was reported as benign and complete resection of the all lesions was performed. The final pathologic examination result was multicystic benign mesothelioma. There are no evidence-based treatment strategies for this rare disease. Complete surgical resection is recommended if feasible.

Keywords: Robotics; mesothelioma

ÖZET Benign kistik mezotelyoma histolojik olarak mezenkimal hücrelerden kaynaklanan peritonun nadir görülen bir tümörüdür. Hastalığa özgü semptomların spesifik olmamasından dolayı operasyon öncesi tanısının konulması oldukça zordur. Bu olgu raporunda robotik tubal reversal operasyonu esnasında karşılaşılan benign kistik mezotelyomanın robotik cerrahi ile tedavisini sunduk. 34 yaşında daha önceden tüp ligasyonu geçiren hasta fertilite isteği nedeniyle tubal reversal amacıyla kliniğimize başvurdu. İntraoperatif batın eksplorasyonunda cul de sac boşluğunun içerisi berrak sıvı ile dolu ince duvarlı multiloküle kistik lezyonlarda oblitere olduğu gözlendi. Frozen sonucunun benign gelmesinden sonra tüm lezyonlar komplet olarak çıkarıldı. Patolojik inceleme sonucu benign multikistik mezotelioma olarak raporlandı. Bu nadir hastalık için kanıta dayalı tedavi stratejisi henüz mevcut değildir. Mümkün olduğunda cerrahi olarak çıkarılmaları gerekir.

Anahtar Kelimeler: Robotiks; mezotelyoma

B enign cystic mesothelioma is a rare intra abdominal peritoneal tumor that usually occurring in females of reproductive age. It typically arises from the mesothelium of the viscera in the pelvis, but may occur in other areas such as intraperitoneal and retroperitoneal spaces. ${ }^{1,2}$ While the origin of the disease is known, the pathogenesis and pathological differential diagnosis remain unclear and controversial. The pre-operative diagnosis of the disease is very difficult due to nonspecific symptoms. There are only 140 cases reported in world literature. ${ }^{3}$ We here report a case of benign cystic mesothelioma which was found incidentally during the robotic assisted 


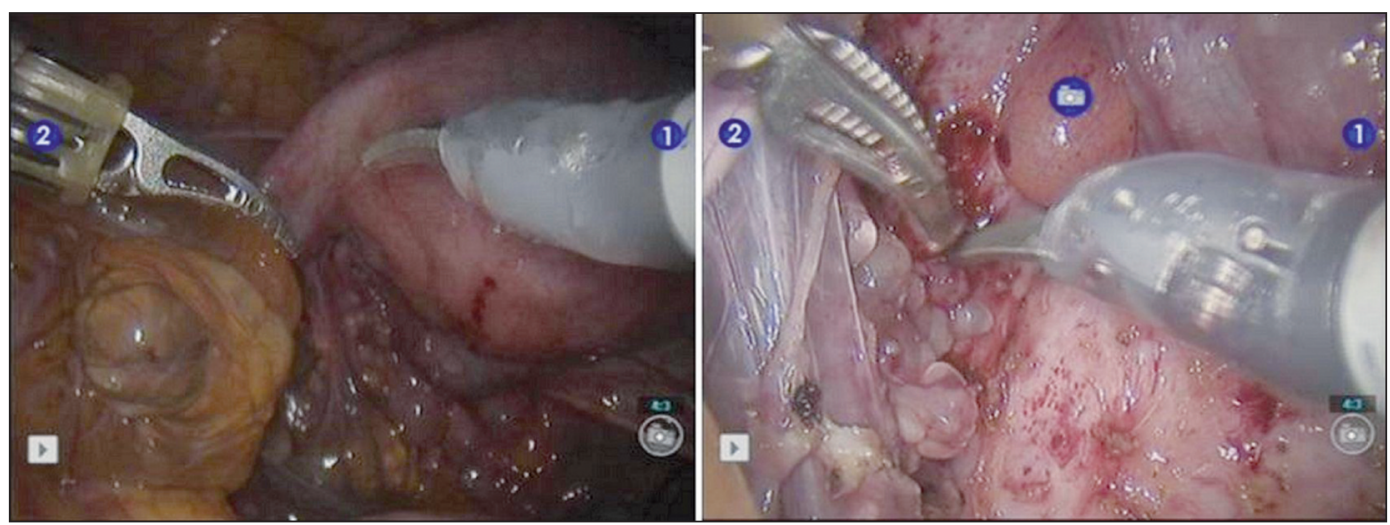

FIGURE 1: Intra operative views of benign multicystic mesothelioma.

tubal surgery. In our knowledge, this is the first reported case treated with robotic assisted surgery.

\section{CASE REPORT}

A 34-year-old female was admitted to the clinic with the request of tubal reversal for return of fertility. In her past medical history, the patient had two cesarean sections and at her last operation, she had bilateral tubal ligation. The other complaint of the patient was chronic pelvic pain for one year period and also she had suffering from dysmenorrhea and dyspareunia. On physical examination, there was no remarkable sign. There was no sign of deep infiltrating endometriosis such as palpable nodule on the sacrouterine ligament or rectovaginal septum. The transvaginal ultrasonography showed predominately cystic lesions with regular margins in different sizes up to $6 \mathrm{~cm}$ at two adnexal regions. She had no history of vomiting, abdominal distension, change in bladder or bowel habits, or loss of appetite or weight. The serum $\mathrm{Ca}-125$ level was within normal limits as well as CEA, CA15-3 and CA 19-9 levels. The patient was informed about the robotic surgery and written informed consent was taken. The da Vinci S surgical system (Intuitive Surgical, Sunnyvale, CA, USA) was used.

Intra operative exploration of the abdomen showed that the obliteration of the cul-de-sac with multiloculated, thin-walled and translucent cysts filled with clear fluids. The cysts were various in size and multiple free intraperitoneal cystic lesions were observed floating in the peritoneal cavity. The largest cyst was seen on the right tubal distal segment which was $6 \times 5 \mathrm{~cm}$ in size (Figure 1). The adhesions were opened and the some of the freefloating cysts were carefully harvested and removed using an endobag for frozen section of pathologic examination. The frozen section was reported as benign and complete resection of the all lesions was performed. After the resection, we performed robotic assisted left tubal renanastomosis. The right tubal reversal was not performed due to hydrosalpinx. The tubal passage was checked with chromopertubation on the left tube and patency of the tube was observed with the passage of the methylene blue. There was no intra operative complication. The patient had an uneventful recovery and she was discharged from hospital at post operative two days. The final pathologic examination result was multicystic benign mesothelioma. She remains free from recurrence 1 year after operation and was closely followed-up by ultrasonography and computed tomography.

\section{DISCUSSION}

Benign cystic mesothelioma is a rare benign tumor of the peritoneum which originates from the mesenchymal cells. The incidence of the disease is $1 / 1.000 .000 .{ }^{4}$ The number of reported cases including benign cystic mesothelioma was found 140 
cases in the literature. ${ }^{3}$ It is usually seen at reproductive age women. The macroscopic properties of the lesions include many cysts in different sizes which are located in abdomen, pelvis or retroperitoneum. The sizes of the lesions may differ numerous milimetric translucent cysts up to $20 \mathrm{~cm}$ in diameter. ${ }^{5}$ The lesions with thin wall are filled with eosinophilic serous fluid. The stoma between cysts contains inflammatory cells and fibrous elements. ${ }^{6}$ Although the pathogenesis of the disease remains unclear, some authors believe that the lesions are neoplastic due to reported cases in the literature in which malign transformation was seen. ${ }^{7,8}$ On the other hand several authors consider this tumor as benign and it's prognosis is excellent. ${ }^{9,10}$

Many neoplastic triggering factors may prove the formation of hyperplasia and transformation of mesothelial cells into the neoplastic cells. In such conditions as the history of hysterectomy, tubal ligation, trauma, pelvic inflammatory disease and endometriosis, the mechanical damage and inflammatory mediators may cause the proliferation of the mesothelial cells and migration and a reactive process is induced. ${ }^{11}$ The role of female sex hormones was considered as in pathogenesis because most of the patients are seen at reproductive age women. ${ }^{12}$ The main symptoms may be lower quadrant abdominal pain and chronic pelvic pain. The preoperative diagnosis of the disease is very difficult. The exact diagnosis is made with pathological examination. The anechoic multiple cystic lesions can be seen during ultrasonography. The size and number of the cystic lesions may be different. The other imaging modalities, magnetic re-sonance imaging (MRI) or computed tomography (BT) may give more information about the localization and sizes of the lesions than ultrasonography. ${ }^{6}$ In the cases with benign cystic mesothelioma in the pelvis localization, ovarian cystic neoplasms (ovarian cystadenoma, cystadenocarcinoma), hydrosalpinx, endometriosis, tuba ovarian abscess should be considered in differential diagnosis. ${ }^{11}$

The most effective treatment of the disease is surgical excision of the lesions. In some studies, the recurrence rate after total surgical excision was reported $50 \% .^{13}$ The suggested surgical approach in some circumstances should include peritonectomy and principles in cytoreductive surgery. In the literature, hormonal therapies with antiestrogens and $\mathrm{GnRH}$ analogs, sclerotheraphy, hypertermic peritoneal perfusion were reported as alternative treatment strategies. There is no role of adjuvant chemotherapy or radiotherapy in the treatment of the disease. ${ }^{11,12}$

Benign cystic mesothelioma is generally considered a benign process; however given the high rate of recurrence and possible malignant transformation, close follow-up is important. There are no evidence-based treatment strategies for benign cystic mesothelioma. The short follow-ups and possible etiologies based on the published reports make it difficult to draw any firm conclusions. Complete surgical resection is recommended if feasible. It requires optimal care in a specialized center especially.

\section{Conflict of Interest}

Authors declared no conflict of interest or financial support.

\section{Authorship Contributions}

Idea/Concept: Fatih Şanlıkan, Ahmet Göçmen

Design: Fatih Şanlıkan

Control/Supervision: Ahmet Göçmen

Data Collection and/or Processing: Fatih Şanlıkan

Analysis and/or Interpretation: Fatih Şanlıkan

Literature Review: Fatih Şanlıkan

Writing the Article: Fatih Şanlıkan

Critical Review: Ahmet Göçmen

References and Fundings: Fatih Şanlıkan

Materials: Fatih Şanlıkan, Ahmet Göçmen. 


\section{REFERENCES}

1. Park JY, Kim KW, Kwon HJ, Park MS, Kwon GY, Jun SY, et al. Peritoneal mesotheliomas: clinicopathologic features, CT findings, and differential diagnosis. AJR Am J Roentgenol 2008;191(3): 814-25.

2. O'Neil JD, Ros PR, Storm BL, Buck JL, Wilkinson EJ. Cystic mesothelioma of the peritoneum. Radiology 1989;170(2):333-7.

3. Witek TD, Marchese JW, Farrell TJ. A recurrence of benign multicystic peritoneal mesothelioma treated through laparoscopic excision: a case report and review of the literature. Surg Laparosc Endosc Percutan Tech 2014;24(2):e70-3.

4. Sugarbaker PH, Acherman YI, GonzalezMoreno S, Ortega-Perez G, Stuart OA, Marchettini $P$, et al. Diagnosis and treatment of peritoneal mesothelioma: The Washington Cancer Institute experience. Semin Oncol 2002;29(1):51-61.
5. Salem S. The uterus and adnexa. In: Rumack CM, Wilson SR, Charboneau JW, eds. Diagnostic Ultrasound. $2^{\text {nd }}$ ed. St Louis, Missouri: Mosby; 1998. p.548.

6. Levy AD, Arnáiz J, Shaw JC, Sobin LH. From the archives of the AFIP: primary peritoneal tumors: imaging features with pathologic correlation. Radiographics 2008;28(2):583-607.

7. González-Moreno S, Yan H, Alcorn KW, Sugarbaker PH. Malignant transformation of "benign" cystic mesothelioma of the peritoneum. J Surg Oncol 2002;79(4):243-51.

8. Hejmadi R, Ganesan R, Kamal NG. Malignant transformation of a well-differentiated peritoneal papillary mesothelioma. Acta Cytol 2003;47(3): 517-8.

9. Mennemeyer R, Smith M. Multicystic, peritoneal mesothelioma: a report with electron microscopy of a case mimicking intra-abdominal cystic hygroma (lymphangioma). Cancer
1979;44(2):692-8.

10. van Ruth S, Bronkhorst MW, van Coevorden F, Zoetmulder FA. Peritoneal benign cystic mesothelioma: a case report and review of the literature. Eur J Surg Oncol 2002;28(2):192-5.

11. Safioleas MC, Constantinos K, Michael S, Konstantinos G, Constantinos S, Alkiviadis K. Benign multicystic peritoneal mesothelioma: a case report and review of the literature. World J Gastroenterol 2006;12(35):5739-42.

12. Uzüm N, Ozçay N, Ataoğlu O. Benign multicystic peritoneal mesothelioma. Turk J Gastroenterol 2009;20(2):138-41.

13. Testa AC, Zannoni GF, Ferrari S, Lecca A, Marana E, Marana R. Benign cystic peritoneal mesothelioma incorrectly diagnosed as an ovarian borderline mucinous tumor of intestinal type at transvaginal preoperative ultrasound evaluation. Ultrasound Obstet Gynecol 2011;37(2): 248-50. 